\title{
The Use Behavior of Tracking and Tracing Services in E-Commerce Logistics
}

\author{
Kinda Rizki Widianti \\ IPB University, Jl. Agatis Kampus IPB Dramaga, Bogor, Babakan, Dramaga, West Java 16680 \\ e-mail: kindarizkiw@gmail.com \\ Eko Ruddy Cahyadi* \\ IPB University, Jl. Agatis Kampus IPB Dramaga, Bogor, Babakan, Dramaga, West Java 16680 \\ e-mail: ekocahyadi@apps.ipb.ac.id \\ Alim Setiawan Slamet \\ IPB University, J1. Agatis Kampus IPB Dramaga, Bogor, Babakan, Dramaga, West Java 16680 \\ e-mail: alimss@apps.ipb.ac.id
}

\begin{abstract}
An increasing business transaction can cause rapid growth in online shops and marketplace. One of the affected is an online shop. From several logistic services, tracking and tracing information services are the main focus in this study because online shops as the business partner have a lack of attention in these services. The objective of this study is to investigate the factors of online shop behavior in using tracking and tracing information services.This study used a unified theory of acceptance and use of technology (UTAUT) as the framework. The quantitative data were collected through questionnaires from 207 samples of online shops selling women's fashion and listed in the marketplace. Data were analyzed using structural equation modeling (SEM) with LISREL 8.70.The result of this study found that "the intention to use" the tracking and tracing information services depend on the effort expectancy (EE) dan social influence (SI), while "user behavior" depends on facilitating condition (FC) and the intention to use. The ease of access factor and learning the tracking and tracing information services are the important factors for the intention to use, whereas electronic devices and internet network factors used by the online shops are the main factors for the user behavior. Logistics companies need to provide information services that can help the online shops in controlling their goods in a good way where the ease of access and learning become the main focus that needs attention. Furthermore, online shops need to facilitate their admins with technological devices and a good internet network to make the admins easy to access information services.
\end{abstract}

Keywords: Logistic services, online shop, tracking and tracing services, UTAUT. 


\section{INTRODUCTION}

The growth of online shop and marketplace begins with the ease of consumers buying goods they need and the transaction process between sellers and buyers becomes more effective and efficient. The impact makes logistics companies in Indonesia competing to improve their services because the relationship between logistics companies and online shops is now a cooperative relationship that benefits both parties. According to Bienstock et al. (2008), service quality was introduced to evaluate logistics capabilities in companies by increasing the value of products or services such as tracking and tracing information, the accuracy of the product received, the accuracy of the location of the recipient, the speed of arrival, the condition of the product, and the right price. From the several logistic services that are currently become the main focus of this research is how logistics companies adapt their tracking and tracing information services.

Tracking and tracing systems are the industry norm for providing services to customers which triggers a competitive advantage for Logistics Service Providers (LSP) (Shamsuzzoha et $a l ., 2013)$. The need for logistic tracking and tracing has been known for a long time, and thus Logistics Service Providers offer to track and collect data services to help problems consumers face in tracking their goods (Huvio et al., 2002). Tracking is a system of collecting and managing information on a product to make it easier for consumers to find their goods while tracing is a system that stores the history of the product distribution cycle and component (Shamsuzzoha et al., 2013). However, the fact is the condition of tracking and tracing information services in Indonesia according to the online shops, has a low level of importance compared to other logistics services (Widianti et al., 2020).

This is certainly different in some countries that consider this service as an important service to advance a business. According to Mirzabeiki et al. (2013) tracking and tracing services are crucial services in supply chain activities in automotive companies in Sweden. This service is significant to reduce losses in a process. Meanwhile, tracking and tracing services are very important to manufacturing companies in managing logistics networks in Finland because tracking and tracing help to identify the delivery position and provide advance notice to its customers (Shamsuzzoha \& Helo, 2011). Functionally, the tracking and tracing information services available in Indonesia have the same functions as those countries, but one factor that makes this service has a low level of importance is the adaptation of technology provided by the logistics company.

The technology provided by the company has different features. Therefore, online shops are often difficult to choose the best tracking and tracing information services. The selection process depends on actual requirements such as costs, waiting times, the convenience of use, etc. To measure the performance potential of each technology, it is necessary to evaluate individual technologies that are suitable for daily needs or the selection process can be analyzed using the Unified Theory of Acceptance and Use of Technology (UTAUT). In UTAUT, logistics companies need to pay attention to the technology that is adapted based on performance expectancy, effort expectancy, social influence, and facilitating conditions for consumers to reuse tracking and tracing services (Vankatesh et al., 2003).

\section{Theoritical Background}

Since the rise of e-commerce or online retailers, many theoretical models of social psychology information systems have been applied to explain or predict consumer adoption, one of them is Theory of Reasoned Action (TRA) theory, Technology Acceptance Model (TAM), Theory of Planned Behavior (TPB), Motivation Model (MM), a combination of TAM and TPB, PC utilization model, Innovation Diffusion Theory (IDT), and Social Cognitive Theory (SCT) (Sedana \& Wijaya, 2009). However, this is still not enough in developing a more comprehensive view (Celik, 2016). UTAUT theory argues that individual intentions towards new technology have four key constructs namely; performance expectancy, effort expectancy, social influence, and facilitating conditions (Venkatesh et al., 2003). According to the model structure, the user's intention to use technology is directly predicted by performance expectancy, effort expectancy, 
and social influence, while the intention to use and facilitating conditions directly determines actual use.

Individual differences affect the utilization of technology. Some literature revealed that anxiety in utilizing technology and personal experience with technology has an inverse relationship, in which when the experience in utilizing technology increases, the anxiety level will decrease (Igbaria \& Chakrabarti, 1990). It is because experience contributes significantly to the development of self-efficacy perceptions of technology and individuals (Brown et al., 2004; Ong \& Lai, 2006; Celik, 2016). Self-efficacy will eventually balance the negative emotional effects on cognitive efforts to process resources for the fulfillment of tasks mediated by technology to generate more expectations (Venkatesh, 2000; Schottenbouer et al., 2004). The theory of acceptance and use in technology is according to the construction of theories and models of technology acceptance (Venkatesh et al., 2003). This model has a variable where PE is performance expectation, EE is effort expectancy, SI is social influence, FC is facilitating condition, $\mathrm{BI}$ is behavioral intention and the latent dependent variable of UB is use behavior (Figure 1)

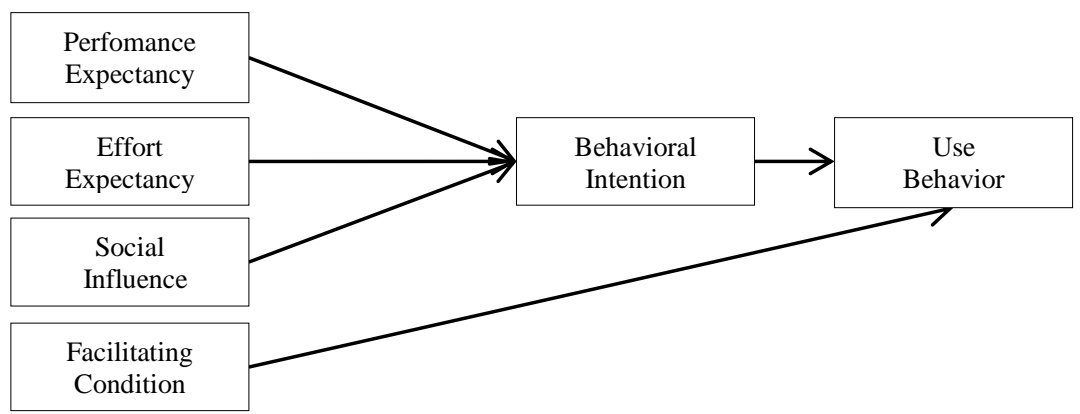

Figure 1. UTAUT Model

Source: Venkatesh et al., 2003

\section{RESEARCH METHOD}

\section{Sampling design and data collection}

The research samples were online shops selling women's fashion like clothes, pants, skirts, shoes, bags, veils, shirts, etc. That were registered in market places and active users of logistics services. The criteria in the sample were obtained through the results of consumer visits to the stores registered in market places. The results showed the stores that sell women's fashion needs frequently visited by consumers in Indonesia.

Data were collected using a questionnaire survey. Sampling was obtained through checking the online shops regularly at market places, then searching for the contacts of the online shops via Instagram, Facebook, and other social media. The process resulted in contacts of the online shops owner to be approached. The decision to distribute questionnaires to owner of online shops could be considered more in-depth since the owner of the online shops felt the impact of profits and losses directly on their experience using information tracking and tracing services of logistics companies. In total, 207 questionnaires were returning with valid survey respondents.

\section{Measurement}

UTAUT model was adopted from previous studies (Venkatesh et al., 2003; Venkatesh \& Zhang, 2010; Wu et al., 2012). The research survey was related to the UTAUT model that built PE (performance expectancy), EE (effort expectancy), SI (social influence), BI (behavioral intention), and UB (use behavior). Model construction in this research was defined based on items that had been proposed by Davis (1989); Ajzen (1991); Venkatesh, et al., (2003); and Awwad and Al-Majali (2015).

\section{Performance Expectancy (PE)}

Performance expectancy is defined as the level of an individual believe that using the system will help and achieve benefits at work (Venkatesh et al., 2003). PE is related to individual 
perceptions about job suitability, usefulness, expected results in using technology (Venkatesh et al., 2003). Based on empirical studies, men tend to be more comfortable with new information systems than women (Venkatesh \& Davis, 2002; Venkatesh et al., 2003), but women will use the system more useful than men (Yi et al., 2005). In previous studies, PE shaped the consumer intentions to use a technology (Venkatesh \& Davis, 2000; Venkatesh et al., 2003; Zhou et al., 2010).

H1 : Performance expectancy (PE) affecting behavioral intention (BI) in using tracking and tracing services.

Effort Expectancy (EE)

Effort expectancy is the comfort level felt in using a system. According to Vankatesh et al., (2003), EE is the level of ease related to using the system. Three models use the EE concept, including TAM 1 and TAM 2, the complexity of PC use, and ease of use (diffusion of innovation theory). Based on empirical studies, EE is a factor in shaping consumer intention to use technology (Venkatesh \& Davis, 2000; Venkatesh et al., 2003; Zhou et al., 2010) and a factor that needs to be considered for its contribution to technology (Orji et al., 2010).

$\mathrm{H} 2$ : Effort expectancy (EE) affects behavioral intention (BI) in using tracking and tracing services.

Social Influence (SI)

Social influence is the level where an individual sees the importance of trusting other individuals in using a system (Venkatesh et al., 2003). SI reflects the influence of other individuals' opinions (Zhou, 2011). Based on empirical studies, women are more sensitive to other individuals' opinions (Venkatesh et al., 2003). SI assumes that consumer intention is influenced by people around the environment and the way that person uses the technology (Awwad \& Al-Majali, 2016).

$\mathrm{H} 3$ : Social Influence (SI) affects behavioral intention (BI) in using tracking and tracing services.

Facilitating Condition ( $F C$ )

Facilitating condition is the level where someone believes that organization and technical infrastructure is available for supporting to use of technology (Venkatesh et al., 2003). Venkatesh et al. (2003) identified empirically that individual intention and facility condition are two direct determinants of individual behavior, based on Awwad and Al-Majali (2016) FC can also serve as a controller of the influence of actual behavior directly (Al Gahtani et al., 2007; Chang et al., 2007; Vankatesh et al., 2003).

H4 : Facilitating condition (FC) affects the use of behavior (UB) in using tracking and tracing services.

Behavioural Intention (BI)

Behavioral Intention is the possibility of customers to use the company's services that have been used and disseminating positive information about the company to the surrounding environment (Othman et al., 2013; Wu, 2015). The UTAUT proved that BI affects UB in using technology (Venkatesh et al., 2003; Venkatesh \& Zhang, 2010).

H5 : Behavioral intention (BI) affects the use of behavior (UB) in using tracking and tracing services.

To test the UTAUT model of this study (Figure 2), indicators built for acceptance in the use of technology of service are based on several previous studies (Martins et al., 2014; Awwad \& Al-Majalo, 2015; Tandijaya, 2018) to form the basis for steps adapted if needed for the context of information services (Table 1). 


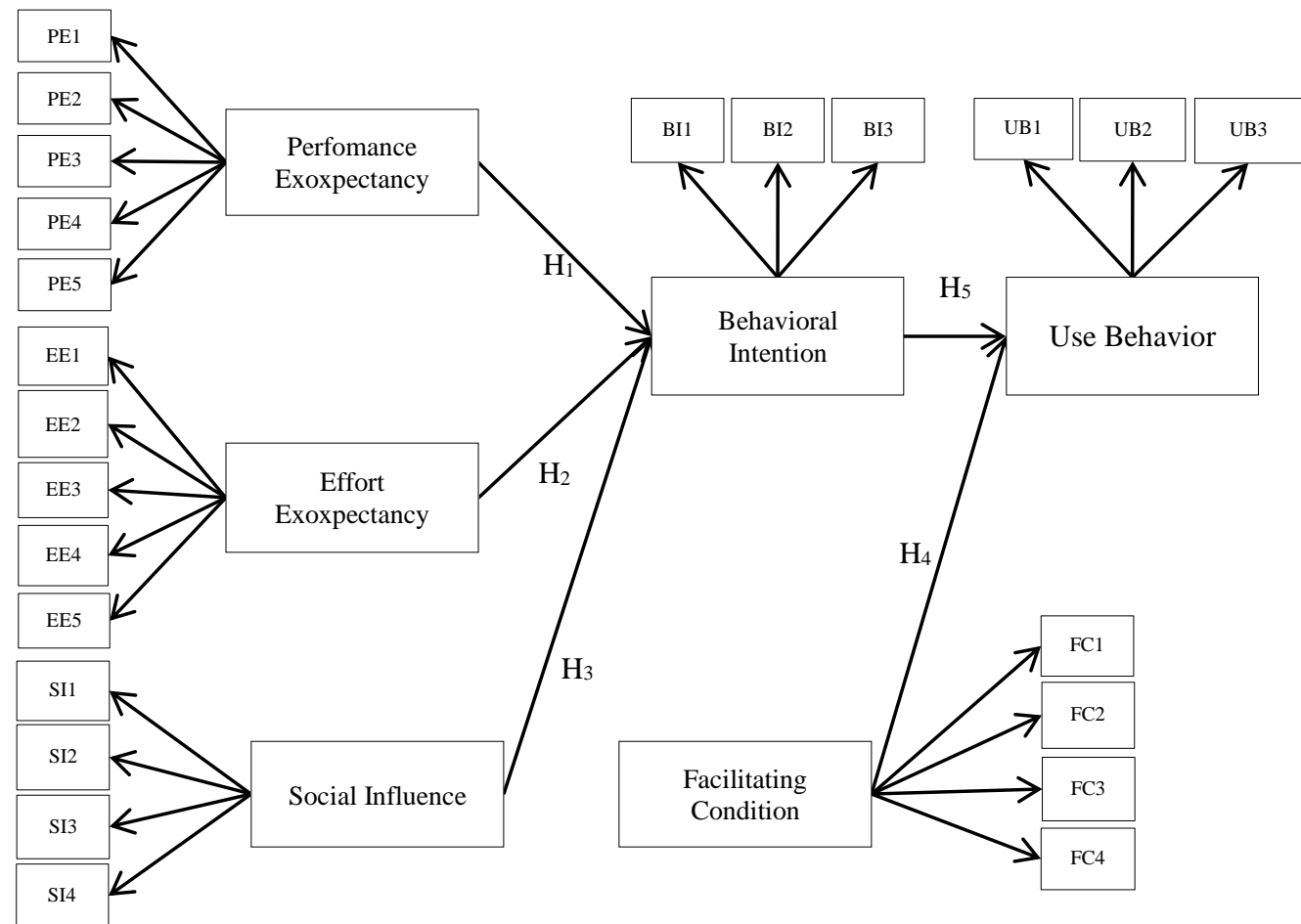

Figure 2. Study Model

Table 1. Indicators of the variables.

\begin{tabular}{|c|c|c|c|c|}
\hline Variable & & & Indicator & Reference \\
\hline \multirow{5}{*}{$\begin{array}{l}\text { Performance } \\
\text { Expectancy }\end{array}$} & PE1 & 1. & $\begin{array}{l}\text { Tracking and tracing information system can } \\
\text { provide complete information }\end{array}$ & \multirow{5}{*}{$\begin{array}{c}\text { (Davis, 1989; } \\
\text { Thompson et al., 1991; } \\
\text { Compeau and Hinggins, } \\
\text { 1995; Awwad and } \\
\text { Al-Majali, 2015) }\end{array}$} \\
\hline & PE2 & 2. & $\begin{array}{l}\text { The tracking and tracing information system } \\
\text { can provide fast information }\end{array}$ & \\
\hline & PE3 & 3. & The tracking and tracing information system & \\
\hline & PE4 & 4. & Tracking and tracing information system can & \\
\hline & PE5 & 5. & $\begin{array}{l}\text { Tracking and tracing information systems have } \\
\text { easy to understand features }\end{array}$ & \\
\hline \multirow{6}{*}{ Effort Expectancy } & EE1 & 6. & Tracking and tracing information system can be & \multirow{6}{*}{$\begin{array}{l}\text { (Davis, 1989; Awwad } \\
\text { and Al-Majali, 2015) }\end{array}$} \\
\hline & EE2 & 7. & $\begin{array}{l}\text { Tracking and tracing information system can be } \\
\text { utilized anywhere }\end{array}$ & \\
\hline & EE3 & 8. & $\begin{array}{l}\text { Tracking and tracing information system is easy } \\
\text { to learn }\end{array}$ & \\
\hline & EE4 & 9. & The capacity of tracking and tracing application & \\
\hline & & 10. & The amount of money used to use tracking and & \\
\hline & EE5 & & tracing application & \\
\hline \multirow{4}{*}{ Social Influence } & SI1 & 11. & $\begin{array}{l}\text { The market place is influential in using the } \\
\text { technology }\end{array}$ & \multirow{4}{*}{$\begin{array}{l}\text { (Davis, 1989; Ajzen, } \\
\text { 1991; Thompson et al., } \\
\text { 1991; Venkatesh et al., } \\
\text { 2003; Martins et al., } \\
\text { 2014) }\end{array}$} \\
\hline & SI2 & 12. & The online shop community is influential in & \\
\hline & SI3 & 13. & Reviews of buyers are influential in using the & \\
\hline & SI4 & 14. & $\begin{array}{l}\text { technology } \\
\text { Competitors from other online shops are } \\
\text { influential in using the technology }\end{array}$ & \\
\hline \multirow{3}{*}{$\begin{array}{l}\text { Facilitating } \\
\text { Condition }\end{array}$} & FC1 & 15. & There are electronic devices that are facilitated & \multirow{3}{*}{$\begin{array}{l}\text { (Ajzen, 1991; Moore } \\
\text { and Benbasat, 1991; } \\
\text { Taylor and Todd, 1995) }\end{array}$} \\
\hline & $\mathrm{FC} 2$ & 16. & An easily accessible internet network & \\
\hline & FC3 & 17. & There is a guide in using the technology & \\
\hline
\end{tabular}




\begin{tabular}{|c|c|c|c|}
\hline Variable & & Indicator & Reference \\
\hline \multirow{4}{*}{$\begin{array}{l}\text { Behavioral } \\
\text { Intention }\end{array}$} & BI1 & Will always use the service some time later & \multirow{4}{*}{$\begin{array}{l}\text { (Zeithaml et al., 1996; } \\
\text { Amoah et al., 2016; } \\
\text { Tandijaya, 2018) }\end{array}$} \\
\hline & $\mathrm{BI} 2$ & Will always use to develop marketing strategies & \\
\hline & & Will recommend services to other online shop & \\
\hline & $\mathrm{BI} 3$ & communities & \\
\hline \multirow{3}{*}{ Use Behaviour } & UB1 & $\begin{array}{l}\text { 21. Have used tracking and tracing information } \\
\text { system regularly }\end{array}$ & \multirow{3}{*}{$\begin{array}{c}\text { (Awwad and Al-Majali, } \\
\text { 2014; Martins et al., } \\
\text { 2014) }\end{array}$} \\
\hline & UB2 & $\begin{array}{l}\text { 22. Have used services to develop marketing } \\
\text { strategies }\end{array}$ & \\
\hline & UB3 & 23. Have used to evaluate logistics performance & \\
\hline
\end{tabular}

\section{Instrument reliability and validity}

The research construct had a standard value of factor loading greater than 0,50 . Reliability measurement was performed using other alternatives by calculating construct reliability (CR). Values were considered good when the $C R$ value was more than the critical value $(C R \geq 0,70)$ (Hair et al., 2010). The validity of the construct was performed using an average where the coefficient value of average variance extracted (AVE) was greater than or equal to the critical value (AVE $\geq 0,50$ ) (Hair et al., 2010). The results of confirmatory factor analysis (CFA) showed that all constructions exceed the critical values (Table 2).

Table 2. The results of confirmatory factor analysis (CFA)

\begin{tabular}{|c|c|c|c|c|}
\hline Construct & Loadings & AVE & $\mathrm{CR}$ & $\mathrm{R}^{2}$ \\
\hline \multicolumn{5}{|c|}{ Performance expectancy (PE) } \\
\hline PE1 & 0,814 & \multirow{5}{*}{0,626} & \multirow{5}{*}{0,893} & \\
\hline PE2 & 0,872 & & & \\
\hline PE3 & 0,773 & & & \\
\hline PE4 & 0,758 & & & \\
\hline PE5 & 0,731 & & & \\
\hline \multicolumn{5}{|l|}{ Effort expectancy (EE) } \\
\hline EE1 & 0,896 & \multirow{5}{*}{0,687} & \multirow{5}{*}{0,916} & \\
\hline EE2 & 0,931 & & & \\
\hline EE3 & 0,835 & & & \\
\hline EE4 & 0,796 & & & \\
\hline EE5 & 0,661 & & & \\
\hline \multicolumn{5}{|l|}{ Social influence (SI) } \\
\hline SI1 & 0,791 & \multirow{4}{*}{0,552} & \multirow{4}{*}{0,831} & \\
\hline SI2 & 0,726 & & & \\
\hline SI3 & 0,780 & & & \\
\hline SI4 & 0,668 & & & \\
\hline \multicolumn{5}{|c|}{ Facilitating condition (FC) } \\
\hline FC1 & 0,846 & \multirow{3}{*}{0,651} & \multirow{3}{*}{0,848} & \\
\hline $\mathrm{FC} 2$ & 0,762 & & & \\
\hline FC3 & 0,810 & & & \\
\hline \multicolumn{5}{|c|}{ Behavioral intention (BI) } \\
\hline BI1 & 0,898 & \multirow{3}{*}{0,788} & \multirow{3}{*}{0,918} & \multirow{3}{*}{0,716} \\
\hline $\mathrm{BI} 2$ & 0,905 & & & \\
\hline $\mathrm{BI} 3$ & 0,860 & & & \\
\hline \multicolumn{5}{|l|}{ Use behavior (UB) } \\
\hline UB1 & 0,844 & \multirow{3}{*}{0,608} & \multirow{3}{*}{0,823} & \multirow{3}{*}{0,894} \\
\hline UB2 & 0,767 & & & \\
\hline UB3 & 0,724 & & & \\
\hline
\end{tabular}

\section{Model fit}

Hair et al., (2010) stated that the index model was used to test the structural model. Table III showed that all indices had a model compatibility values exceeding the level of each general acceptance as suggested in the previous studies. The results of the model fit in this study indicated that the model showed good compatibility with the data collected where the value had greater than standard threshold in this model fit. 
Table 3. The goodness of fit indices for the structural model

\begin{tabular}{lcc}
\hline Fit indices & Threshold & Value \\
\hline GFI (goodness of fit index) & $>0,90$ & 0,802 \\
RMSEA (root mean square error of approximation) & $\leq 0,05$ & 0,050 \\
NNFI (non-normed fit index) & $\geq 0,90$ & 0,985 \\
NFI (normed fit index) & $\geq 0,90$ & 0,969 \\
CFI (comparative fit index) & $\geq 0,90$ & 0,987 \\
RFI (relative fit index) & $\geq 0,90$ & 0,964 \\
\hline
\end{tabular}

\section{RESULT AND DISCUSSION}

\section{Online shop characteristics}

Descriptive analysis regarding the online shop characteristics is presented in Table 4. The results show the percentage of online shop domiciles in the Jabodetabek area (53 percent), the Bandung area (29 percent), and other areas (18 percent). The highest percentage of the age of the owners of the online shops is in the range of $21-25$ years ( 40 percent), while the lowest percentage is $<20$ years ( 3 percent). Meanwhile, the percentage of the duration of the established online shops is $1-5$ years (52 percent), 6-10 years ( 26 percent), less than 1 year (21 percent), and more than 10 years ( 1 percent)

\begin{tabular}{lcc} 
Table 4. Characteristics of Sample & & $(\%)$ \\
\hline Characteristic & Frequency & 53 \\
\hline Domicile of the online shop & 109 & 29 \\
Jabodetabek & 61 & 18 \\
Bandung & 37 & \\
Others & & 40 \\
Age of online shop owner & 82 & 31 \\
$21-25$ years & 64 & 14 \\
$26-30$ years & 30 & 7 \\
$31-35$ years & 15 & 8 \\
$36-40$ years & 16 & \\
$>40$ years & & 21 \\
Length of business & 43 & 52 \\
$<1$ year & 107 & 26 \\
$1-5$ years & 55 & 1 \\
$6-10$ years & 2 & \\
$>10$ years & & \\
\hline
\end{tabular}

\section{The Use of tracking and tracing services}

According to online shops, the use of the tracking and tracing services has some functions in several categories. Figure 3 shows the use of the tracking and tracing information services in the logistics companies. The results show that 179 online shops use services to control the arrival of goods to consumers. 175 online shops use services to respond to consumers' complaints. 170 online shops use the services to evaluate the arrival time of the goods to the consumers. 147 online shops use the services to recapitulate the customers who buy the goods in their stores. The last, 128 online shops use the services to evaluate the quantity or volume of shipments in the past year. The results show that approximately 25 percent of online shops do not use the functions of tracking and tracing information services optimally at the logistics company. 


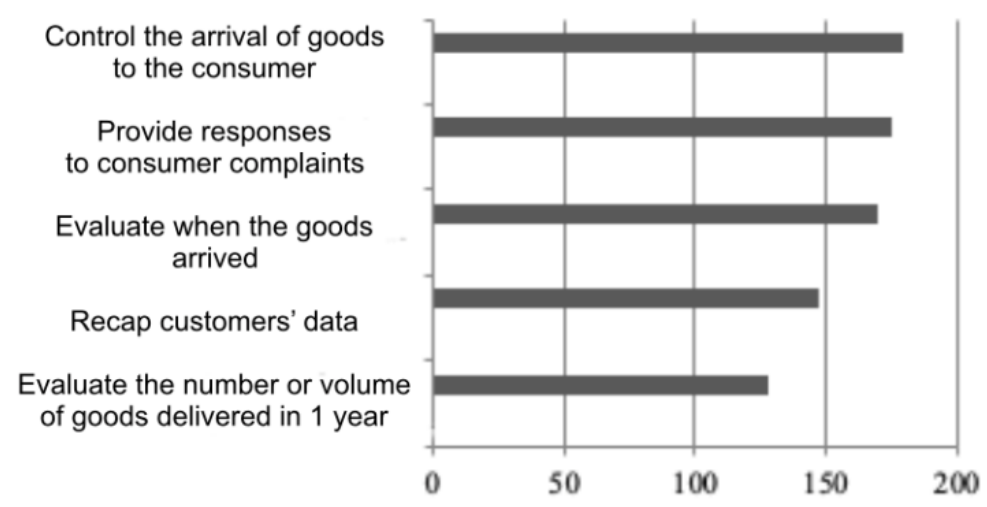

Figure 3. Use of tracking and tracing information services for online shops

\section{Hypothesis Testing}

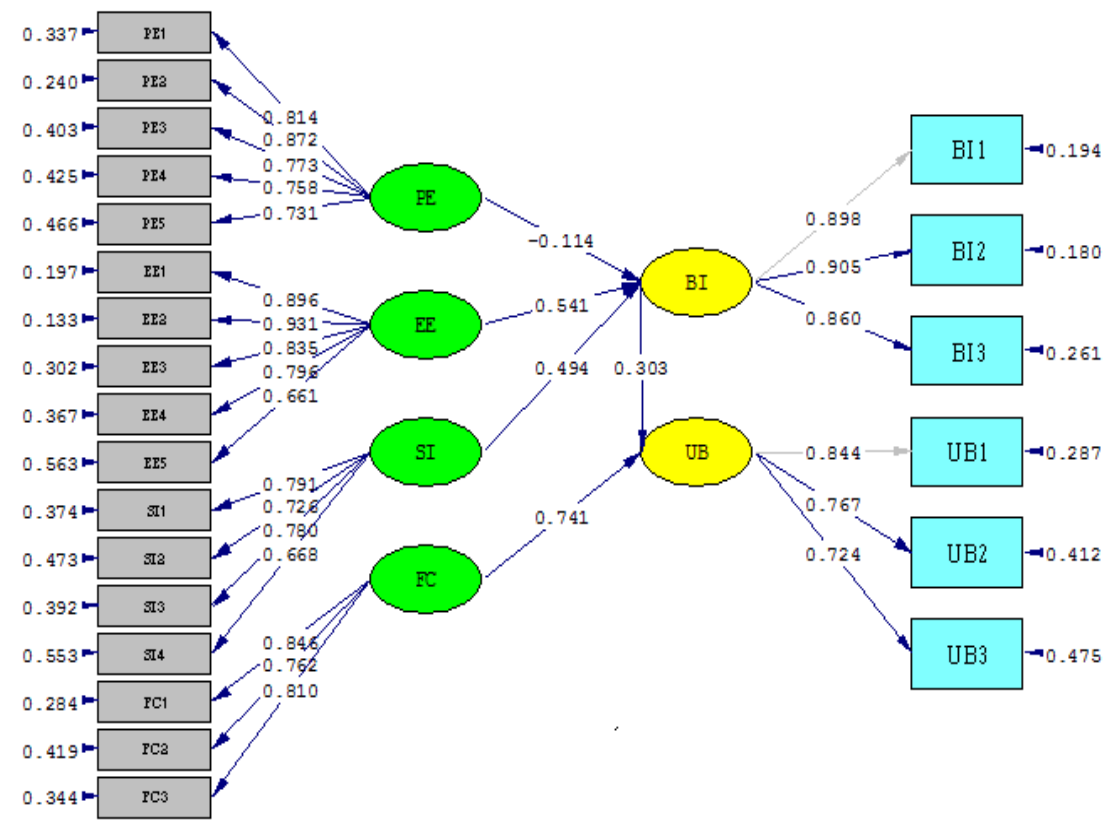

Figure 4. Results of structural model

This research used structural equation modeling (SEM) approach to develop model that represented a causal relation between research variables using LISREL 8.70. Figure 4 and Table 5 represent the results of testing the model.

Table 5. Result of Hypothesis Test

\begin{tabular}{cclccc}
\hline Hypotheses & & & & $\beta$ & $t$-value \\
\hline H1 & Performance expectancy & $\rightarrow$ & Behavioral intention & $-0,114$ & $-1,1015$ \\
H2 & Effort expectancy & $\rightarrow$ & Behavioral intention & 0,541 & $6,288^{* * *}$ \\
H3 & Social influence & $\rightarrow$ & Behavioral intention & 0,493 & $3,927 * * *$ \\
H4 & Facilitating condition & $\rightarrow$ & Use behavioral & 0,741 & $7,527 * * *$ \\
H5 & Behavioral intention & $\rightarrow$ & Use behavioral & 0,303 & $3,419 * * *$ \\
\hline
\end{tabular}

The Effect of Performance Expectation (PE) toward Behavioral Intention (BI)

From the result, path coefficient value was $-0,114$. It showed that the relation between Pefomance Expectation (PE) with Behavioral Intention (BI) was negative. It means that if the Pefomance Expectation (PE) increased then Behavioral Intention (BI) would decrease, and vice versa. The relation between the Performance Expectation (PE) and Behavioral Intention (BI) was not significant in the 2-tailed test $(\mathrm{t}$ table $=-1,96)$ with a -t-count value of $-1,015$ greater than $-\mathrm{t}$ table. Thus, $\mathrm{H} 1$ was rejected. It means that Performance Expectation (PE) did not significantly

Jurnal Manajemen dan Organisasi (JMO), Vol. 12 No. 1 April 2021, 
affect Behavioral Intention (BI). These results were in accordance with several studies of Atmojo et al. (2016), in his study, the absence of the influence of PE on BI caused an individual's instructional motivation to service providers of products and IT service implementers. It did not give the desire to utilize a knowledge management system (KMS) system to improve their work performance. In addition, research from Putri (2019) states that the insignificance between PE and $\mathrm{BI}$ is due to the assumption that there is an application whether or not a user can still conduct transaction activities.

\section{The Effect of Effort Expectancy (EE) toward Behavioral Intention (BI)}

As the result, the path coefficient value was 0,541. It showed that the relation between Effort Expectancy (EE) and Behavioral Intention (BI) was positive. It means that if Effort Expectancy (EE) increased, Behavioral Intention (BI) would increase, and vice versa. The relation between Effort Expectancy (EE) and Behavioral Intention (BI) was significant in the 2 -tailed test $(\mathrm{t}$ table $=1,96)$ with a $\mathrm{t}$-test value of 6,288 greater than $\mathrm{t}$ table. Thus, $\mathrm{H} 2$ was accepted. It means that Effort Expectancy (EE) significantly affected Behavioral Intention (BI). The effect of EE on BI in using a large effect for online shop on their intention to use information services was in line with the research of Venkatesh et al. (2003) and several other inventors such as Sitanggang et al. (2017); Foon and Fah (2011); and AbuShanab et al. (2010) stated that information services provided by companies were not difficult to use by consumers. This made an individual more comfortable in using the information service because it was flexible.

\section{The effect of Social Influence (SI) toward Behavioral Intention (BI)}

From the result, the path coefficient value was 0,494. It showed that the realtion betwen Social Influence (SI) and Behavioral Intention (BI) was positive. It means that if Social Influence (SI) increased, Behavioral Intention (BI) would increase, and vice versa. The relation between Social Influence (SI) and Behavioral Intention (BI) was significant in the 2-tailed test ( $\mathrm{t}$ table $=$ 1,96) with a t-test value of 3,927 greater than $\mathrm{t}$ table. Thus, $\mathrm{H} 3$ was accepted. It meant that Social Influence (SI) significantly affected Behavioral Intention (BI). The effect of SI on BI had a lower effect compared to EE. Yet, this research was in line with several studies such as Venkatesh et al. (2003) and Sitanggang et al. (2017). Most online shops stated that the use of information services occurred because of the limitations of the choice of market place. Thus, the effect of intention to use was mandatory.

\section{The Effect of Facilitating Condition (FC) toward Use Behavior (UB)}

From the results, path coefficient value was 0,741 . It showed that the relation between Facilitating Condition (FC) and Use Behavior (UB) was positive or unidirectional. It means that if Facilitating Condition (FC) increased, then Use Behavior (UB) would increase, and vice versa. The relation between Facilitating Conditions (FC) and Use Behavior (UB) was significant in the 2-tailed test $(\mathrm{t}$ table $=1,96)$ with a t-test value of 7,527 greater than $\mathrm{t}$ table. Thus, $\mathrm{H} 4$ was accepted. It means that Facilitating Condition (FC) significantly affected the Use Behavior (UB). The effect of FC on UB was a big influence for online shop behavior in using the information service. This research was in line with the research of Venkatesh et al. (2003) that stated the greatest effect because of the electronic devices used in operating the information service.

\section{The Effect of Behavioral Intention (BI) toward Use Behavior (UB)}

Based $n$ the result, path coefficient value was 0,303. It showed that the relation between Behavioral Intention (BI) and Use Behavior (UB) was positive or the same direction. It means that if the Behavioral Intention (BI) increased, the Use Behavior (UB) would increase, and vice versa. The relation between Behavioral Intention (BI) and Use Behavior (UB) was significant in the 2-tailed test ( $t$ table $=1,96)$ with a calculated value of 3,419 greater than $t$ table. Thus, H5 was accepted. It means that Behavioral Intention (BI) significantly affected the Use Behavior (UB). The effect of BI on UB was one of the influences on online shop behavior in using the information service in accordance with research conducted by Venkatesh et al. (2003) and Atmojo et al. (2016). In addition, other factors towards the intention to use the information service was because of the desire of the online shop to improve their business strategies. 


\section{Implication}

Logistic company needs to develop information service to increase for the online shop to continue to use the information service. The results showed that the lack of online shop behavior in using the information service was because the expectations desired by the online shop were not met by the information service. The presence and absence of tracking and tracing information services at these companies did not affect their buying and selling transactions with their customers (Putri, 2019) or the existence of a tracking and tracing information service that could access all logistic companies making it easier for online shops to use these services. To overcome this obstacle, management at the logistics company in Indonesia must create a way to make an online shop that always checks the goods that have been delivered to the customer. This action can be conducted by means of a bar-code link on the goods with information services. Thus, it will be easy to control each movement of goods. Other advantages besides end consumers, online shops will also know the process where the goods are damaged or lost. This eases online shops to answer complaints from end customers by activating customer service for 24 hours to answer complaints either from online shops or from end customers.

\section{Limitation and Further Research}

As in all research, this research also has some limitations. The research was conducted only to online shops that sell women's fashion needs. Therefore, future research needs to be conducted by other fields of online shops that have a very large urgency level. Thus,there is a big possibility that the online shop always controls the position of the goods sent to consumers. The current Research is conducted in Indonesia and there is a lack of reference comparisons with consumers of non-online shop logistics companies. Therefore, further research needs to look at how other consumers' behavior in using information tracking and tracing services is expected to be a difference in behavior between consumers and online shops in using information tracking and tracing services.

\section{REFERENCE}

Ajzen, I. (1991). The Theory of Planned Behavior. Organizational Behavior and Human Decision Processes, 50(2), 179-211.

Awwad, M. S., \& Al-Majali, S. M. (2016.) Electronic library services acceptance and use: An empirical validation of unified theory of acceptance and use of technology. The Electronic Library, 33(6), 1100-1120.

Al-Gahtani, S., Hubona, G., \& Wang, J. (2007). Information Technology (IT) in Saudi Arabia: culture and the acceptance and use of IT. Information and Management, 44(8), 681-691.

Bienstock, C. C., Royne, M. B., Sherrell, D., \& Stafford, T. F. (2008). An expanded model of logistics service quality: incorporating logistics information technology. International Journal of Production Economics, 113(1), 5-22.

Celik, H. (2016). Customer online shopping anxiety within the unified theory of acceptance and use technology framework. Asia Pacific Journal of Marketing and Logistics, 28(2).

Chang, I. C., Hwang, H. G., Hung, W. F., \& Li, Y. C. (2007). Physicians' acceptance of pharmacokinetics-based clinical decision support systems. Expert Systems with Applications, 33(2), 296-303.

Davis, F. D. (1989). Perceived Usefulness, Perceived Ease of Use, and User Acceptance of Informa-tion Technology. M IS Quarterly,13(3), 319-339.

Hair, J. F., Black, W. C., Babin, B. J., \& Anderson, R. E. (2010). Multivariate Data Analysis, 7th ed., Prentice Hall, Upper Saddle River, NJ.

Huvio, E., Gronvall, J., \& Framling, K. (2002). Tracking dan Tracing Parcels Using A Distributed Computing Approach. Norwegian University of Science and Technology, Trondheim, Norway, 29-43.

Mirzabeiki, V., Holmstrom, J., \& Framling, K. (2013). Collaborative Tracking and Tracing: The Value of A Composite Design. The International Journal of Logistics Management, 25(1), $522-536$. 
Orji, R. O., Cetin, Y. Y., Ozkan, S., White, B., \& One, D. (2010). Critical factors in electronic library acceptance: empirical validation of nationality based UTAUT using SEM. IADIS International Conference, 81-88.

Othman, Z., Zahari, M. S. M., \& Radzi, S. M. (2013). Customer behavioral inten-tion: influence of service delivery failures and service recovery in Malay restaurants. Proce-dia-Social and Behavioral Sciences, 105,115-121.

Putri, R. A. (2019). Peminat Aplikasi Blibli.com Dengan Menggunakan Model Unified Theory of Acceptance and Use of Technology (UTAUT). Jurnal Riset Bisnis dan Manajemen, 12(1), 16-23.

Sedana, I. G. N., \& Wijaya, St. W. (2009). Penerapan model UTAUT untuk memahami penerimaan dan penggunaan learning management system studi kasus: experiential e-learning of sanata dharma university. Journal of Information Systems, 50(2), 114-120.

Shamsuzzoha AHM dan Helo P.2011.Real-time Tracking dan tracing System: Potentials for the Logistics Network. International Conference on Industrial Engineering and Operations Management Kuala Lumpur.

Shamsuzzoha AHM, Mikael E, Richard A. Tenkorang. 2013. Perfomance Evaluation of Tracking and Tracing for Logistics Operations. Int. J. Shipping and Transport Logistic, 5(1).

Sitanggang, M., Bendi, R. K. J., \& Soejono, F. (2017). Analisis Perilaku Penggunaan Sistem Informasi Akademik Oleh Mahasiswa Keperawatn. Jurnal sistem dan teknologi informasi komunikasi, 1(1), 11-22.

Venkatesh, V., Morris, M., Davis, G., \& Davis, F. (2003). User acceptance of information technology: Toward a unified view. MIS Quarterly, 27(3), 425-478.

Venkatesh, V., \& Zhang, X. (2010). Unified theory of acceptance and use of technology: US vs China. Journal of Global Information Technology Management, 13(1), 5-27.

Widianti, K. R., Cahyadi, E. R., \& Slamet, A. S. (2020). The effect of online shop owner satisfaction on logistic services (comparative study of JNE dan J\&T Express). Indonesian journal of business and entrepreneurship, 6(2), 196 - 204.

Wu, H. C. (2014). The effects of customer satisfac-tion, perceived value, corporate image and ser-vice quality on behavioral intentions in gaming establishments. Asia Pacific Journal of Market-ing and Logistics, 26(4), 540-565.

Yi, Y., Wu, Z., \& Tung, L. L. (2005). How individual differences influence technology usage? Towards an integrated framework. Journal of Computer Information Systems, 46(2), 52-63.

Zhou, T., Lu, Y. B., \& Wang, B. (2010). Integrating TTF and UTAUT to explain mobile banking user adoption. Computers in Human Behavior, 26(4), 760-767. 